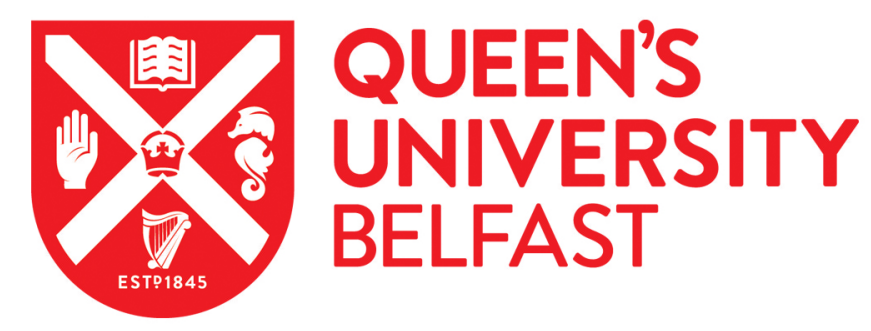

\title{
A European Law of New Health Technologies
}

Flear, M., Farrell, A-M., Hervey, T., \& Murphy, T. (2013). A European Law of New Health Technologies. In M. Flear, A-M. Farrell, T. Hervey, \& T. Murphy (Eds.), European Law and New Health Technologies (pp. 389-414). (Oxford Studies in European Law). Oxford University Press. https://global.oup.com/academic/product/europeanlaw-and-new-health-technologies-9780199659210?cc=gb\&lang=en\&\#

\section{Published in:}

European Law and New Health Technologies

\section{Document Version:}

Early version, also known as pre-print

\section{Queen's University Belfast - Research Portal:}

Link to publication record in Queen's University Belfast Research Portal

\section{Publisher rights}

Copyright 2013 OUP

This is a draft of a chapter that was published by Oxford University Press in the book European Law and New Health Technologies edited by Mark L Flear, Anne-Maree Farrell, Tamara K Hervey, and Thérèse Murphy published in 2013.

\section{General rights}

Copyright for the publications made accessible via the Queen's University Belfast Research Portal is retained by the author(s) and / or other copyright owners and it is a condition of accessing these publications that users recognise and abide by the legal requirements associated with these rights.

\section{Take down policy}

The Research Portal is Queen's institutional repository that provides access to Queen's research output. Every effort has been made to ensure that content in the Research Portal does not infringe any person's rights, or applicable UK laws. If you discover content in the Research Portal that you believe breaches copyright or violates any law, please contact openaccess@qub.ac.uk. 


\section{PART V}

\section{BRINGING IT ALL TOGETHER}


Comp. by: PG2689 Stage : Revises1 ChapterID: 0001797202 Date:12/12/12 Time:12:59:30

OUP UNCORRECTED PROOF - REVISES, 12/12/2012, SPi 


\title{
A European Law of New Health Technologies?
}

\author{
Mark L Flear, Anne-Maree Farrell, Tamara K Hervey, \\ and Thérèse Murphy*
}

\section{A. European Law and New Health Technologies}

Setting out on this project, we asked ourselves: What—if any—are the defining features of European law approaches to new health technologies? What is the significance of European law to such technologies? To what extent and, if so, how is European law on new health technologies legitimated? What are-and what should be-the roles of markets, risk, rights, and ethics in that respect? Thus, our initial overarching research agenda concerned the relationships between European law and new health technologies.

In this chapter, we reflect on those relationships. In so doing, we ask a further question: To what extent does our investigation define a new field of scholarshipEuropean law of new health technologies? To sharpen our focus, we begin by reflecting on our core concepts: first, 'new health technologies' and thereafter 'European law'.

\section{New Health Technologies}

What counts as a 'new health technology'? We do not offer a new singular definitionnor did we hope to do so. The concept seems to be insufficiently defined for both discursive practices (in varied contexts including academic, policymaking, and legislative) and effective regulation. This imprecision might well be quite deliberate and pragmatic: the risk of running behind the pace of scientific, and social, development gives both academics and policymakers good reason to eschew precise definitions.

But novelty is not necessarily a temporal phenomenon. ' 'Old technology' can become 'new technology' where new applications or new linkages make its use more controversial. ${ }^{2}$ Researchers and medical practitioners differ in what counts as a 'new' health technology. ${ }^{3}$ Intellectual property also drives claims of newness. ${ }^{4}$ Side effects, misconduct, and accidents also have profound effects on what is 'new'. ${ }^{5}$ Novelty can thus be understood as almost entirely context-specific.

\footnotetext{
* Our thanks to David Fraser for an insightful peer review.

1 eg some 'biotechnology medicines', such as recombinant insulin, have been on the market in the EU since the 1980s, see Chapter 2 in this collection.

2 eg new applications of in vitro fertilization, see T Murphy, 'Repetition, Revolution, and Resonance' in T Murphy (ed), New Technologies and Human Rights (OUP 2009). See also Chapter 15 in this collection.

3 Chapter 4 in this collection.

4 Chapters 4 and 7 in this collection.

5 See eg A Petryna, Life Exposed: Biological Citizens after Chernobyl (Princeton UP 2002).
} 
What counts as 'new' may depend ultimately on human perceptions-what is seen or constructed as new, socially not just scientifically. ${ }^{6}$ Thus, the visibility of technological developments may be more important than we imagine. Consumer, patient, or public attitudes to new health technologies, including whether they are desirable or undesirable, which feed into regulatory arrangements through democratic processes, depend more on perceived novelty than intrinsic qualities of a new (health) technology. Recognizing novelty as constructed explains why differences between perceived incremental change and perceived radical change also matter: the former is perceived as fundamentally less threatening, challenging, and risky than the latter.

Challenges of defining 'new health technology' also reflect the well-known difficulties in determining the meaning of 'health'. Consider one of the widest definitions of health, that of the World Health Organization (WHO), and contrast this with the definitions found in the UN Millennium Declaration, or the Agreement on Trade-Related Aspects of Intellectual Property Rights (TRIPs). The former declares that 'the enjoyment of the highest attainable standard of health is one of the fundamental rights of every human bring without distinction of race, religion, political belief, or economic or social condition', and defines health as 'a state of complete, physical, mental and social wellbeing and not merely the absence of disease or infirmity'. 7 The latter, by contrast, focus upon those with the greatest health needs, for instance through the concept of 'essential medicines', or treating medically recognized disabilities or illnesses. ${ }^{8}$

Finally, what counts as a 'new health technology'? Going beyond medicines, medical devices, and surgical procedures, such technologies encompass organizational systems for health care provision, screening, technologies of health information, and 'eHealth'. ' Even the simple technology of a book ${ }^{10}$ challenges our notion of 'new health technology' and reminds us that novelty is not necessary instantiated in ways we might expect.

Our practical response to the definitional challenges was to leave the question of what counts as a 'new health technology' to our contributors: they represent a reasonably wide range of expertise. Reflecting on their approaches and choices, what can we learn? First, by and large, our contributors excluded 'green' technologies, ${ }^{11}$ although of course these have important implications for (global) health. For example, the 'Green Revolution' of the 1960s and 70s was supposed to alleviate hunger in the global South; ${ }^{12}$ relationships between genetically modified crops and allergies are

6 Chapter 10 in this collection explores the concept of 'newness' in detail, drawing on the field of nanotechnology. On 'social not just scientific' see A Webster, Health, Technology and Society: A Sociological Critique (Palgrave Macmillan 2007) 171-5. See relatedly S Jasanoff, 'Experiments Without Borders: Biology in the Labs of Life', BIOS Annual Lecture, LSE 15 June 2006 <http:// www.lse.ac.uk/bios> accessed 24 July 2012: 'I think that British politics of science and technology produces more dramatic pictures than America's, and more of British politics happens, a result, in the visual domain.... some of the best pictures that show what's going on in the public domain are produced [in the UK].'

7 Constitution of the WHO, 22 July 1946, 14 UNTS 185 (1948), preamble.

8 See further J Harrington and M Stuttaford (eds), Global Health and Human Rights (Routledge 2010); J Tobin, The Right to Health in International Law (OUP 2012); B Toebes (ed), Health and Human Rights in Europe (Intersentia 2012); B Toebes (ed), Health and Human Rights in Europe (Intersentia 2012).

9 In the sense of technological support in health care practice, see the second Regulator's perspective in Part II of this collection.

10 Chapter 15 in this collection.

11 cf Chapter 10 in this collection.

12 GS Khush, 'Green Revolution: Preparing for the 21st Century' (1999) 42 Genome 646; K Mechlem and T Raney, 'Agricultural Biotechnology and the Right to Food' in F Francioni (ed), Biotechnologies and International Human Rights (Hart 2007). 
insufficiently understood; ${ }^{13}$ bioremediation has important health implications. ${ }^{14}$ The list could go on. Instead, the focus was primarily on 'red' technologies, which encompass the design and application of biomedicine. This focus is perhaps understandable given the use of such technologies to diagnose or alleviate (medically recognized) illness or disability. In any case, it represents an initial and important way forward towards considering the nature and scope of new health technologies, as well as offering an opportunity to expand the research agenda through the inclusion of, and/or comparison with, 'green' technologies in the future.

Secondly, the phrase 'new health technologies' resonates on at least three different levels. ${ }^{15}$ It denotes a small number of generic groupings of types of technologies (for example, products, processes, or methods of using products). It can mean forms of technology organized by scientific or technical sphere. Or it can mean specific examples of these forms, with their applications. Our book offers a 'map' within which relationships between these different levels can be explored. ${ }^{16}$

Thirdly, within the field of 'new health technologies' we also find many definitional problems. ${ }^{17}$ Law did not produce all of these problems; it does perpetuate them, however. For instance, European law distinguishes between pharmaceuticals/medicinal products, medical devices, treatment protocols/processes/therapies, surveillance, and diagnosis; ${ }^{18}$ between curative, prophylactic, enhancing, and cosmetic technologies; between technologies for diagnosis, treatment, and monitoring; between pharmacological, immunological, or metabolic versus mechanical modes of action. Many of these distinctions are unconvincing in the context of new health technologies. New health technologies also overlap with categories generated by the interplay between science and regulation, ${ }^{19}$ which have applications both within and outside health contexts. New health technologies thus fundamentally challenge the internal logics of Europe's regulatory regimes (particularly those of the European Union (EU)). ${ }^{20}$ This challenge is one of the reasons for our frame of inquiry.

But what are the implications of the definitional conundrums that are highlighted here? First, regulatory authorities, forced to work within these definitional constraints, may struggle or fail to keep pace with technological developments, leading to a constant process of differentiation and adaptation through various mechanisms of governance to maintain (a degree of) connection. ${ }^{21}$ Secondly, it can be unclear which regulatory regime

13 The Royal Society, 'Genetic Modified Plants for Food Use and Human Health: An Update' (Royal Society, Policy Document 4/02, 2002) <http://royalsociety.org/uploadedFiles/Royal_Society_ Content/policy/publications/2002/9960.pdf> accessed 18 July 2012.

14 Bioremediation involves the use of micro-organisms to remove marine pollution, see Chapter 4 in this collection.

15 As demonstrated by Chapter 4 in this collection in an analysis inspired by patent law.

16 Chapter 4 in this collection. In similar vein, drawing out the concept of 'legal cartography', see B de S Santos, Toward a New Legal Common Sense: Law, Globalization and Emancipation (2nd edn, Butterworths 2002).

17 Questions about definitions within the concept of 'new health technology' are picked up by several of the chapters in this collection, eg: Chapters 5, 7, 8, 12, and 15.

18 Chapter 4, Section XX and Table 4.1.

19 Such as synthetic biology, nanotechnology, and biotechnology.

20 See eg the following from this collection: Chapters 4, 9, 10, 12, and 16.

21 See eg the following chapters in this collection: Chapters 9 and 12 and the first Regulator's Perspective in Part II and the Regulator's Perspective in Part III. On connection and new technologies, see more generally R Brownsword, Rights, Regulation, and the Technological Revolution (OUP 2008); R Brownsword and M Goodwin, Law and the Technologies of the Twenty-First Century (CUP 2012) 369420 . 
applies, and due to the lack of clear legal definitions, undesirable regulatory gaps may appear. ${ }^{22}$

Thirdly, in the context of supranational/multilevel governance environments, technical or scientific developments which bring newness to health technologies are accompanied by complexity and even confusion arising from definitional imprecision. The problem of reaching consensus in European institutions (including science) makes governance of change a difficult task. It produces a resistance to unpicking what is agreed, contributing to the accumulation of a legal and regulatory heritage, and a potential misfit with new developments. ${ }^{23}$ This highlights a paradox of technological novelty, yet often a response of governance continuity. There may be no easy solutions here except to allow for purposive disconnection between new health technologies and their governance, permitting the re-evaluation of definitional difficulties as and when they arise following implementation and practice, ${ }^{24}$ and to adjust and reconnect accordingly. ${ }^{25}$

\section{European Law}

In our opening chapter, we defined 'European law' as wider than the law of the EU, encompassing the law of the Council of Europe, as well as that of organizations such as the European Patent Office, the OECD, and WHO Europe. Moreover, because these overlapping legal orders reach into national legal orders in ways that belie hierarchical relations, we also conceptualize European law as both multilevel and pluralist. ${ }^{26}$ Equally, we conceive 'law' as a much wider category than 'legislation' and 'case law', with the legal institutions that develop it. 'Law' also includes within it ways in which these 'modes of governance' (if that is the 'meta-category') interact with regulatory strategies, including soft law such as technical guidelines, reporting obligations, and benchmarking and indicators. ${ }^{27}$

Arguably, our focus on European law was too narrow. If health technology is a global industry, why single out a European dimension? Perhaps our reference point should have been global law-for instance, including the law of the International Conference on Harmonisation of Technical Requirements for Registration of Pharmaceuticals for Human Use, the WHO UNESCO, and the World Trade Organization? Should we have discussed law from other jurisdictions, that is applied or avoided in European contexts? And why European law? Should we have had 'regulation', or even 'governance' as our central focus? However broadly one draws 'law', it is difficult to think of it as the 'meta-category', particularly once we depart from the nation-state as the geographical reference point or scale.

22 As Chapter 12 in this collection notes for 'combined products'; similarly Chapter 8 in this collection points to the difficulties of defining drug delivery through nanotechnology, or innovative tissue engineering, in the terms of EU product liability law, which draws on the distinctions between 'medicinal products', 'medical devices', and 'blood, organs, human tissue and cells'.

23 Chapters 10 and 12 in this collection.

24 Chapter 5 in this collection.

25 eg the decision of the Court of Justice of the European Union (CJEU) in Case C-316/09 MSD Sharp \& Dohme GmbH v Merckle GmbH 5 May 2011 nyr prompted the EU Commission to propose amended legislation on information about prescription-only pharmaceuticals on the internet, see $\operatorname{COM}(2012) 48$ final.

26 Several of our contributors report on the implications of European law in various national contexts, see especially Chapters 5 and 8 in this collection.

27 Such as found in the EU's 'new governance' approaches, see J Scott and DM Trubek, 'Mind the Gap: Law and New Approaches to Governance in the European Union' (2002) 8 European Law Journal 1; M Dawson, New Governance and the Transformation of European Law (CUP 2011). 
But there are both practical and conceptual reasons for our focus. The practical reasons were discussed in the opening chapter of the book. If one sees European law as a multilevel pluralist legal system (and we do), the law of new health technologies in Europe is European law. In the policy and (some) legal discourse, and crucially in the discourses of the actors involved (regulators, industries, patients' groups, and the like), 'European' has a meaning —or, more precisely, a range of meanings. These encompass the different and arguably competing interests and aims of law and regulation-be they ethical, scientific, commercial/market, socio-cultural-concerning new health technologies and the multi-valuing of humans, their bodies, human cells, blood, tissue, and organs. ${ }^{28}$ As outlined later, these are often presented as calibrated and 'in tune', but often essentially masking their (perhaps arguable) inherent incompatibility.

The conceptual reasons focus around heritage and, relatedly, imagined futures. Europe is home to many technological firsts, including both Louise Brown, the first 'test-tube' baby, and Dolly the sheep, the first successful attempt at cloning a mammal by means of nuclear transfer technology. It is the home, too, of legal experimentation. Consider the EU: it is neither state nor international, instead 'it stands between them, incorporates strains of each and interlocks with them both'. ${ }^{29}$ The EU Charter of Fundamental Rights (EUCFR) is distinctive too. For instance, it establishes data protection as an autonomous fundamental right, a move that makes it stand out amongst human rights instruments which, by and large, hook data protection onto the right to privacy. ${ }^{30}$ Or consider the European Court of Human Rights (ECtHR), praised as 'the crown jewel of the world's most advanced international system for protecting civil and political liberties' 31 and home to a body of case law that features strongly in the common law of human rights ${ }^{32}$ - that is, in the migration of human rights ideas from one legal regime to another. And, just as interesting, in this common law realm, the ECtHR is both exporter and importer. ${ }^{33}$

Overall, these related institutional forms ensure that Europe's governance responses do not develop from a 'clean sheet', but are conditioned by what went before. Of course, this might generate both misfit between existing definitions or understandings and new developments, and regulatory gaps. It also means that 'European law' holds resources that can be refashioned and redeployed to 'keep up' and close any gaps, so as to govern in the face of the uncertainty, 'unknowing', 'cross-borderness', ${ }^{34}$ and to shape technoscientific developments and futures.

28 Chapter 9 in this collection, Section XX

29 N Walker, 'The Place of European Law' in J Weiler and G de Búrca (eds), The Worlds of European Constitutionalism (OUP 2011) xx.

${ }_{30}$ See European Union Agency for Fundamental Rights, Data Protection in the European Union: The Role of National Data Protection Authorities (Publications Office of the EU 2010) 6.

31 L Helfer, 'Redesigning the ECHR: Embeddedness as a Deep Structural Principle of the European Human Rights Regime' (2008) 19 European Journal of International Law 125, 159.

32 See C McCrudden, 'A Common Law of Human Rights' (2000) 20 Oxford Journal of Legal Studies 499; C McCrudden, 'Judicial Comparativism and Human Rights' in E Örücü and D Nelken (eds), Comparative Law: A Handbook (Hart 2007).

33 See, respectively, Opuz v Turkey, App No 33401/02, Judgment of 9 June 2009 (wherein the ECtHR makes reference to communications of the UN Committee on the Elimination of All Forms of Discrimination against Women), and Lawrence v Texas 539 US 558 (2003) (wherein the US SCt makes reference to ECtHR case law).

${ }^{34}$ A term coined by Zhang, Marris, and Rose to describe a key but neglected regulatory challenge in the field of synthetic biology: JY Zhang, C Morris, and N Rose, 'The Transnational Governance of Synthetic Biology: Scientific Uncertainty, Cross-borderness and the "Art" of Governance' (2011) BIOS Working Paper No 4. 
Indeed, Europe-encompassing European institutions, European governments, and European publics-is also the home of a range of imagined new-health-technology futures. These futures link in part to European pasts, actual (whether acknowledged or neglected) and possible. ${ }^{35}$ They also link to the non-European: the EU, for instance, endorses a precautionary approach that has led to it being brought before a Panel of the WTO. ${ }^{36}$ The influence of the non-European might also grow in the future in that the EU has been pitching itself as an actor in the international human rights field. This raises a host of interesting questions, including how going forward it can govern science and technology so as to avoid giving 'scientific' endorsement to ideas of racial superiority, and thereby give effect to the International Declaration on the Elimination of All Forms of Racial Discrimination: in its Preamble the latter emphasizes that 'any doctrine of racial differentiation or superiority is scientifically false, morally condemnable, socially unjust and dangerous, and that there is no justification for racial discrimination either in theory or in practice.'

Imagined futures, not surprisingly, draw heavily on markets. Individual European states see themselves in a race to techno-innovate; the EU is also in this race, having vowed to use scientific research to build the most competitive global-knowledge economy. ${ }^{37}$ More speculatively, there may be distinctively European imaginaries around other ideas that organize much of the thinking, in Europe and elsewhere, on how new health technologies might be governed-ideas ranging from dignity to crossborderness, to what can and cannot be patented, and who should have a say in such matters. Any such imaginaries will, of course, exert regulatory force, both in Europe and outside it, and both aspirationally and aversively (or, as some prefer to say, by means of 'policy learning').

In terms of why 'law' (rather than, say, governance), law remains an important part of the governance environment for new health technologies in Europe. Part of the reason is the way law engages with novelty. For instance, in the EU context, the European Medicines Agency's Road Map; or horizon scanning, through EuroScan on health technology assessment, stress the novelty of the science, rather than its continuity. ${ }^{38}$ The ECtHR addresses the scientific and social novelty of new health technologies, which it represents as not only new, ${ }^{39}$ but rapidly developing. This justifies the need to develop appropriate legal responses, which also includes anticipating developments in knowledge that could not be foreseen at the time of adjudication. ${ }^{40}$ In both of these contexts there are some notable attempts to respond to novelty through new legal or regulatory ideas or institutions. Take, for instance, the rise of public bioethics: in the EU, through the European Group on Ethics in Science and New Technologies (EGE) and ethics committees; and in respect of the Council of Europe, the Oviedo

\footnotetext{
35 See eg G de Búrca, 'The Road Not Taken: The EU as a Global Human Rights Actor' (2011) 105 American Journal of International Law 649; B Prainsack and R Gmeiner, 'Clean Soil and Common Ground: The Biopolitics of Human Embryonic Stem Cell Research in Austria' (2008) 17 Science as Culture 377, examining the impact of the past on Austria's stance on reproductive medicine.

36 EC-Measures Affecting the Approval and Marketing of Biotech Products, Panel Reports WT/ DS291/R, WT/DS292/R, WT/DS292/R, 29 September 2006.

37 See eg Lisbon European Council Presidency Conclusions, 23-24 March $2000<$ http:www. europarl.europa.eu/summits/lis1.en.htm\#a> accessed 16 July 2012; European Commission, 'Europe 2020: A Strategy for Smart, Sustainable and Inclusive Growth' COM(2010) 2020 final.

38 Chapter 4 in this collection.

39 Of course, the technology at issue in SH and Others was not so new; as the applicants contended, it was 'common and readily available', and 'reliable'.

40 Chapter 13 in this collection.
} 
Convention ${ }^{41}$ and the ECtHR's use of 'emerging consensus' in respect of new health technologies. ${ }^{42}$

Yet, in other examples, and arguably the dominant picture overall, existing legal ideas (rights, dignity, liabilities, authorization, etc.) and 'regulatory heritage' 43 (path dependency) are used to deal with what is at the same time presented as novel. For example, in the Council of Europe context, these might constitute 'fixed reference points'. ${ }^{44} \mathrm{EU}$ product liability law treats new health technologies in the same way as any other product. In fact, it strengthens the legal fiction that a comparative product is any other product in its 'development risks defence', which protects producers from liability for defects that could not be discovered at the time the product is put into circulation. ${ }^{45}$ New health technologies, such as nanotechnology, are deemed insufficiently new to warrant new regulatory responses. ${ }^{46}$ This reversion to pre-existing regulatory institutions, tools, and techniques, in an approach that can be described at best as 'incremental regulatory innovation' ${ }^{47}$ is 'arguably the most pronounced feature of the EU's regulatory response to nanotechnology'. ${ }^{48}$ So, in some important respects, European law of new health technologies not only is not so new itself, but also paradoxically quite often does not conceive of new health technologies as 'really new'. This dominance of legal continuity is therefore the reason for our focus on law.

Moreover, given the increasing attention paid to 'hybridity' and blurred boundaries between different forms of law, ${ }^{49}$ between law and regulation, and in seeking optimal 'governance blends', we do of course need to think in terms of law's place- of how it does, and how it should, relate to other modes of governance..$^{50}$ But in so doing we must not lose sight of law. To guard against that risk, there needs to be attention to the particular — not just particular fields of law (intellectual property, crime, human rights) but also to particular legal and non-legal settings where the governance of new health technologies is determined or resisted. Our view is that law's part-including the part played by European law - in the governance of new health technologies is shaped by at least two forces. It is shaped, first, by the ways in which legal and non-legal forms of governance (ethics, for instance) are seen by legal actors and institutions. Secondly, it is shaped by the ways these different forms of governance are seen by non-legal and hybrid institutions and actors. 51

There is one final, definitional point: Why European law and new health technologies?

41 Chapter 3 in this collection.

42 Chapter 13 in this collection.

43 Chapter 10 in this collection.

44 Chapter 3 in this collection.

45 Chapter 8 in this collection.

46 Chapter 10 and 12 in this collection.

47 Chapter 12 in this collection, 15.

48 Chapter 10 in this collection Section XX.

49 See eg Chapter 2 in this collection; F Cafaggi, 'New Foundations of Transnational Private Regulation' (2011) 38 Journal of Law and Society 20; G de Búrca and J Scott, 'Introduction: New Governance, Law and Constitutionalism' in G de Búrca and J Scott (eds), Law and New Governance in the EU and US (Hart 2006); G de Búrca, 'New Governance and Experimentalism: An Introduction' (2010) Wisconsin Law Review 227.

50 The first Regulator's Perspective in Part II of this collection. See also SHE Harmon, G Laurie, and F Arzuaga, 'Foresighting Futures: Law, New Technologies, and the Challenges of Regulating for Uncertainty' (2012) 4 Law, Innovation and Technology 1.

51 See further Chapter 13 in this collection; the various Regulators' Perspectives in this collection. 
Why not, for example, European law and new technologies? Or European law and health? Or even European law and rights in health contexts? There are interesting questions here of classification and its consequences. There are also, we accept, existing strands of scholarship focused on each of these possible, alternative fields. This book, we think, contributes to those existing bodies of literature. But it also claims to do-or at least to attempt-more. It asks: Is there a distinctive 'European-ness' to the relationships between European law and new health technologies? And so we turn to our second main section of this chapter-to the defining features of European law approaches to new health technologies where we consider whether there is a European law of new health technologies.

\section{B. Defining Features of European Law Approaches to New Health Technologies}

Our inquiry began with the intuition that, if there is a European law of new health technologies, it is typified by a certain 'European-ness' in terms of four features: markets, risk, human rights, and ethics. The four frames are demonstrably overlapping and, in general, mutually supporting. This phenomenon presents us with some organizational difficulties in the text that follows. Rather than break up the flow of our discussion, or attempt to present an exhaustive coverage of all possible combinations of the four frames, we begin by considering each frame alone, before turning to examine some of the more pertinent combinations.

\section{Four Frames}

\section{a. Markets}

One (perhaps the) traditional economics view of the role of markets as a mode of governance is that markets promote free trade, which fosters efficiency. The role of law and other governance mechanisms is to 'hold the ring' for rational economic actors within a free market, and to correct for market asymmetries. ${ }^{52}$ In other words, law or regulation is 'second best' to markets. ${ }^{53}$ As examined in various chapters in this book, the relationship between markets, law, and regulation in the context of European law of new health technologies is more complex and nuanced than that account.

In the context of the EU, the market is the dominant frame for law on new health technologies. ${ }^{54}$ Almost every area of the relevant EU law, especially its legislation, and the regulatory institutions and practices that surround it, refers to the market as its rationale. These references range from access of new products or services to the EU market; to regulation of research with a view to eventual marketing to protection of consumers (patients) once a new health technology is on the market. Even legislation that appears to have a stronger rationale than that of the market ${ }^{55}$ is framed as being

52 Such as informational asymmetries which might impede such rational behaviour.

53 See T Prosser, The Regulatory Enterprise (OUP 2010) 2, drawing on one of the seminal works in the law and economics field of regulation: A Ogus, Regulation: Legal Form and Economic Theory (Hart 2004).

54 Chapter 2 in this collection.

55 eg the EU's Directive on Legal Protection of Biotechnological Inventions, which in many ways concerns the ethics of allowing patent protection on controversial inventions, eg those involving embryonic stem cells. 
centrally concerned with the market. ${ }^{56}$ The entire structure of EU regulation of new health technologies, the way the regulatory measures fit together, cross-refer to each other, and are justified, all concern the marketing of new health technologies. At a level of generality (though not at every aspect of the regulatory landscape), the EU's approach to risk, rights, and ethics is essentially all about the need to create, foster, and protect the EU's market.

Law and its supporting institutions are therefore used by the EU to facilitate market arrangements with respect to new health technologies. These legal concepts and institutions include (a) 'services' in health care; (b) the notion of 'product', especially 'safe product', for instance as applied to new health technologies that also involve parts of the human body; and (c) the institution of the 'competent authority', a trans-European requirement that presents itself as ensuring market parity for various actors within the context of development, production, and use of new health technologies.

Relevant EU regulation refers to the EU's 'internal market', and the perceived need for removal of barriers to trade within it, so as to optimize growth and economic opportunity for inventors, developers, producers, and distributors of new health technologies operating within the EU. Equally, patients have used the EU law focus on the internal market to escape perceived deficiencies in the regulatory environments in their home state. Likewise, Member States have used the 'safety valve' of availability of treatment abroad to sustain their regulatory choices in the face of local criticism. ${ }^{57} \mathrm{In}$ this assessment, the market rationale of EU law of new health technologies is legitimate. Pluralist arrangements whereby different countries may have different rules, but may not impede consumer (patient) access to markets in other countries, increases consumer (patient) choice and 'exit' from sub-optimal national regulatory arrangements.

By contrast, prizing a legally harmonized single EU market more highly than consumer rights has negative effects for consumers in countries where, for instance, prior to harmonization, product liability laws gave greater protection to consumers. The 'freezing' of EU law in time is also sub-optimal, as the law can fail to keep pace with technological developments. ${ }^{58}$ The underlying rationale of EU legislation, to the effect that there is a single (albeit regulated) EU market in all products, is also flawed. The market for new health technologies is not a normal consumer-led market: the main 'consumers' are national health systems, and they do not behave like normal consumers - their decision-making is significantly more politically constrained. Similarly, 'slight deviations in domestic implementation' can be interpreted as leading to too much heterogeneity for optimal regulation, in terms of creating the space necessary for innovation to be translated into clinical or health care settings. 59

Moreover, the binary division in European law between 'products' (which are the subject of 'ordinary' market trade, though may be regulated heavily if safety or quality is at issue) and 'the human body' (which is not, in European contexts, to be traded) is tested to destruction by the emergence of certain new health technologies. ${ }^{60}$ The ways

56 As strikingly seen in the Brüstle case in which the CJEU differed from the opinion of its AG to articulate a market-based rationale, rather than one based on dignity.

57 eg Austria bars ova and sperm donation for IVF but recognizes the parental status of those who have gone abroad for treatment: see Chapter 13 in this collection. See also T Hervey, 'Buy Baby: The European Union and Regulation of Human Reproduction' (1998) 18 Oxford Journal of Legal Studies 207.

58 Chapter 9, Sections XX in this collection, 9, 11.

59 This argument is implicit in Chapter 5, Section XX in this collection.

60 Such as collagen scaffolds, for instance the decelluralized homograft valve being developed in Hannover's regenerative medicine research cluster: see Chapter 5 in this collection. 
in which that binary division has infused the EU's legislative and regulatory structures for new health technologies (including the ways in which they are implemented in national contexts) not only provide opportunities for both a regulatory 'race to the top' as well as a 'race to the bottom', but can also be seen as nothing short of 'a manifestation of injustice'. ${ }^{61}$ A comparison with the US approach highlights the deficiencies of the European law of this aspect of new health technologies. The implication is that, as a knowledge-based economy, the EU is not well served by the law. Of course, beyond the nation-state, law's reach is limited, as it represents the outcome of often intense political bargaining in a complex multilevel governance environment, with all of its messiness, deficiencies, and necessary silences or omissions designed to assuage political conflict.

EU law also refers to the place of the EU's new health technology industries within the global market, and the desirability of designing the EU's governance structures so as to optimize the ability of EU firms to compete there. ${ }^{62}$ The ways in which individuals seek to escape or avoid governance arrangements within Europe that are perceived as sub-optimal are part of the way in which the global market frames European governance. A 'level playing field' is legitimated by pursuit of European industry's competitiveness in global markets. In addition, it could be argued that the EU uses its approach to governance in the field of health technologies as a way of positioning itself as a leading global actor in the field, by exporting its legal style to the global stage. ${ }^{63}$

Finally, in terms of the market frame, we note that new health technologies do not emerge fully formed de novo on the market, ready to be regulated, and only then become subject to law. Rather, law shapes the conditions for the emergence of new health technologies, their eventual constitution, and concrete manifestations and effects. As several of the chapters show, the market for new health technologies is created - through discourses of hope and expectation, promulgated by clinicians, patients, regulatory agencies, and health authorities.

\section{b. Risk}

The case studies of new health technologies in this book show that, in European contexts, it is not contested that a range of governance mechanisms is necessary to regulate risk. Furthermore, European law conceptualized as 'command and control' or as 'legislate and adjudicate' will capture only a small part of the story-hence our focus on law, whilst at the same time taking account of regulation and wider social norms.

The assessment and management of risk in the context of uncertainty and the legitimacy of risk-management institutions and regulatory structures resonates particularly in European contexts in relation to emerging new health technologies. ${ }^{64}$ The legitimacy of EU governance of new health technologies may be assessed by reference to procedural or constitutional institutional standards; democratic standards; ${ }^{65}$ functional or effectiveness standards; or value-based standards, depending on the objectives of the regulatory regime. ${ }^{66}$ This latter conceptualization resonates strongly with risk-based standards of assessing the EU's regulatory regime for new health technologies, as the

61 Chapter 5, Section XX in this collection.

62 Chapter 12, Sections XX in this collection.

63 For an example of the EU's approach in this regard in the case of environmental policy, see RD Kelemen, 'Globalizing European Union Environmental Policy' (2010) 17 Journal of European Public Policy 335.

${ }^{64}$ Nanotechnology being the prime contemporary example here.

65 Such as participation, transparency, deliberation, accountability.

66 Chapter 9 in this collection. 
expressed values of the EU's relevant legislation place 'consumer' or even 'patient' safety centre frame. In terms of effectiveness, the EU's regulatory strategies can be seen to be deficient, in that they tend to lock regulatory responses into established analytical frameworks, rather than being open to 'variation and evolution over time and between contexts', ${ }^{67}$ lacking comprehensiveness and leaving regulatory gaps, and revealing deficiencies in regulatory capacity. ${ }^{68}$ Effective EU governance of new health technologies needs to move beyond the 'risk as safety' frame, to conceptualize risk as a social and cultural construct, shaped by public perceptions and ethical concerns. ${ }^{69}$

In addition to the problems created by such a narrow construction of risk, the structures of $\mathrm{EU}$ law $^{70}$ also operate in practice to privilege relationships between regulators and the pharmaceutical industry, to the detriment of clinical investigators. ${ }^{71}$ Implicit in this analysis is that EU law (as part of the global regulation of pharmaceuticals) is woefully inadequate to protect patients against risk. Moreover, the legal threat of enforcing contractual provisions with respect to confidentiality at least affects the timing of release of information about clinical trials to the scientific community and/or regulatory authorities, and may operate to intimidate some researchers into silence. Far from protecting patients against risk, in this account the 'dark side' of the law is instrumentalized to protect a powerful industry, which has integrated itself with both regulatory authorities and research institutions (universities) alike. ${ }^{72}$

As implied earlier, risk in EU law on new health technologies is normally conceptualized as patient, or even consumer, safety. However, this is not always the case. Risks faced by industries with respect to regulatory uncertainty and sub-optimality also feature fairly strongly in the relevant legal and policy instruments. The calculation of risk varies as between expert and non-expert views. ${ }^{73}$ There is a tendency in the EU to focus almost exclusively on expert calculations of risk, and this is a key part of the 'regulatory heritage' of new health technologies in that context. ${ }^{74}$ Equally, in EU law, the policy and regulatory debate is said to follow a peculiarly narrow trajectory focused around risk. ${ }^{75}$ This 'European' approach to risk, which has been characterized as essentially protectionist, may be contrasted with the US approach, which is said to view risk as opportunity. ${ }^{76}$

The EU's reliance upon risk regulation of new health technologies as a means of legitimation ${ }^{77}$ can be seen through considering three main factors: ${ }^{78}$ the 'fit' of risk as

67 Chapter 10 in this collection.

68 Chapter 12 in this collection.

69 Chapter 9 in this collection.

70 In particular, the narrow notion of locus standi in judicial review claims before the CJEU.

71 Chapter 11 in this collection.

72 Chapter 11 in this collection.

73 Chapter 8 in this collection.

74 Chapter 10 in this collection, using examples from nanotechnology.

75 Chapter 10 in this collection.

76 There is a diversity of views on point. Eg it has also been argued that the difference between the EU and the USA is one of process (EU) versus product (USA) in relation to risk assessment: see $S$ Jasanoff, Designs on Nature: Science and Democracy in the United States and Europe (Princeton UP 2005) 83. See further JB Wiener, MD Rogers, JK Hammitt, and PH Sand, The Reality of Precaution: Comparing Risk Regulation in the United States and Europe (RFF Press 2011); D Vogel, The Politics of Precaution: Regulating Health, Safety, and Environmental Risks in Europe and the United States (Princeton UP 2012).

77 Chapter 10' analysis in this collection of European Parliamentary discourse around nanotechnology; Chapter 9's, analysis in this collection of management of risks to public health from new health technologies.

78 Chapter 9 in this collection. 
defined by EU regulation with risk and ethics' concerns of relevant actors; the 'immanent critique' of whether regulation meets its stated aims; and the procedural arrangements for facilitating transparency and evaluation of the regulatory regime. The EU continues to make claims that its regulation of risk enhances public trust, even where assessing risk to consumers, patients, or the public within standard epistemologies is fundamentally challenged by the novelty of health technologies. ${ }^{79}$ Moreover, far from opening up debate through legal requirements of transparency and accountability, in the context of a powerful global pharmaceutical industry, European law can be used to close down contestation, and to narrow the debate among medical experts and other relevant stakeholders. ${ }^{80}$

So far, we have considered, of course, only one element of European law of new health technologies: EU law. One inquiry suggested that the Council of Europe does not feature in the (standalone) market frame: however, as regards the risk frame, we would argue that it is present as 'rights as risk' ${ }^{81}$ By this we mean the potential for human rights to operate as a risk when failure to comply with rights or otherwise meet the requisite standards undermines institutional or organizational reputation and standing. Human rights, in other words, are an 'institutional risk' that must be managed. But the imbalance in coverage needs to be addressed further, and to do so we turn now to the third of our legitimating frames: human rights. The law of the Council of the Europe and the law of the EU are present here. We also find both domestic and international human rights law, as well as a range of rights- and anti-rights activism (some of which might link to what science and technology studies (STS) describes as 'biocitizenship'). ${ }^{82}$

\section{c. Human rights}

Generally, human rights operate as a kind of bridge between theoretical and emotional grounds for action-and from there to the fundamentally practical. Put differently, there is a strong empowering and instrumental dimension to human rights; they provide a form of attention to the world that underpins action that might disrupt or shape trajectories in innovation, through concrete techniques and practices, especially law. Indeed, this might be part of the reason why some have asked if they will replace (bio) ethics in the governance of the life sciences and related technologies. ${ }^{83}$

Human rights, on the face of it, are an important dimension of European law of new health technologies. There is no shortage of legal rules (albeit some of them are on the 'softer' end of the rule-spectrum): most notably, there is the European Convention on Human Rights (ECHR), the European Charter of Fundamental Rights (EUCFR), and both the European Social Charter and the Oviedo Convention, as well as rights protections (including direct incorporation of the ECHR) in the legal frameworks of individual European states. More than this, rights-based approaches to the regulation of new health technologies have been recommended by advisory groups such as the EGE. ${ }^{84}$ The EU, given both the commitment to seek accession to the ECHR and the status of

\footnotetext{
79 Such as nanotechnology, see Chapter 10 in this collection.

80 Chapter 11 in this collection.

81 Chapter 17 in this collection. On 'rights as risk' and 'risk within rights', see more generally T Murphy, Health and Human Rights (Hart 2013 forthcoming) ch 4.

82 Chapter 13 in this collection.

83 Chapter 14 in this collection; Chapter 13 in this collection.

84 See eg G Hermerén, 'Accountability, Democracy, and Ethics Committees' (2009) 2 Law, Innovation and Technology 153; House of Commons Committee on Science and Technology, 'Human Reproductive Technologies and the Law' HC 7, 2004-2005.
} 
the EUCFR, also seems to be signalling its own human rights intentions, perhaps a more coherent human rights policy than previously. ${ }^{85}$ And, the ECtHR, for its part, seems alert both to the need for substantive rights protections and to the ways that human rights encourage, or even mandate, certain principles of governance. ${ }^{86} \mathrm{It}$ is also alert to new technologies as a threat to human rights, and to the ways that new 'techno-enabled' rights could threaten the balancing of rights and interests mandated by, for instance, Article 8 ECHR. ${ }^{87}$

There is, however, a counter-story. As regards health, it could be said that EU law has been less about human rights and more about rights to information, to provide services, and to avail of such services. ${ }^{88}$ More generally, the European Economic Community at its inception may well have been more human rights-robust than today's EU. ${ }^{89}$ The lack of cases on new health technologies before the ECtHR is, of course, another reason to doubt the centrality of human rights law to European law of new health technologies. Relatedly, the ECtHR usually provides a wide 'margin of appreciation' to contracting states when it considers that there is no European consensus, 'either as to the relative importance of the interest at stake or as to the best means of protecting it, particularly where the case raises sensitive moral or ethical issues. ${ }^{90}$

Still, there is a direction of movement in the jurisprudence of the ECtHR towards increasing scrutiny of national policies in contexts where health technologies are developing. ${ }^{91}$ More importantly, in terms of European law of new health technologies - specifically, in terms of human rights having not just a role in the governance of new health technologies but a role that could be said to be distinctively European-the margin of appreciation doctrine ${ }^{92}$ seems to be central. We say this for two reasons. First, this doctrine is an ongoing experiment in the negotiation of a core human rights question and, relatedly, of European identity: namely, how to achieve a balance between universalism and particularism? Secondly, the doctrine signals the productive nature of European law: the ECtHR does not simply reflect consensus, but can also be seen to play a significant role in creating the consensus. ${ }^{93}$ In similar vein, as we discuss later, because the ECtHR sees human rights as having a procedural dimension, rights may also shape what is expected both when European law of new health technologies is 'in the making' and when that law aims to be 'future proof' ${ }^{94}$

Attention to human rights also highlights how the European law of new health technologies is pluralist — but with a minimum core. This is apparent in, for example, the notion of margin of appreciation and in strong variations in terms of national interpretations of EU law at the stage of implementation of EU Directives. $95 \mathrm{New}$

85 The call for greater coherence was made, eg, in 'Leading By Example: A Human Rights Agenda for the European Union for the Year 2000'.

86 Chapter 3 in this collection.

87 See respectively $S$ and Marper $v$ United Kingdom [GC] (2009) 48 EHRR 50 at para 71, 112; Odièvre v France [GC] (2003) 38 EHRR 871.

88 Chapter 6 in this collection; Chapter 17 in this collection. See further TK Hervey and JV McHale, European Union Health Law (CUP 2014 forthcoming).

89 As Gráinne de Búrca has argued (n 35).

90 Evans v United Kingdom [GC] (2008) 46 EHRR 34, para 77.

91 Examples include gender reassignment surgery, and the relatively strong steer given to contracting states, as well as strong dissenting opinions, in cases concerning ARTs. See Chapters 3 and 13 in this collection.

92 Chapter 3, Section C and Chpater 13 in this collection.

93 Chapter 3, Section $\mathrm{C}$ and Chpater 13 in this collection.

94 See text at nn 105 and 159. See more generally Chapters 3 and 13 in this collection.

95 Chapters 5, 8, 9, 10, 12, and 17 in this collection. 
health technologie, as many have noted, raise issues of deep and reasonable disagreement: constitutional pluralism is how Europe manages these disagreements, and both constitutes itself as a distinct order in the global system and projects itself within it by offering examples of governance approaches to new health technologies.

Within the general framework of pluralism, we discern a 'minimum core' of nonnegotiable substantive European law of new health technologies. Emanating from the Council of Europe, and implicit in the ECtHR's jurisprudence, this minimum core focuses around human rights (mainly 'civil and political' rights, but also to some extent economic and social rights) —in particular, rights related to autonomy or privacy, ${ }^{96}$ as well as to some extent equality and the right to health. ${ }^{97}$ In EU law, the non-negotiable focuses on the right to privacy and related rights. Thus, human rights in the European law of new health technologies are not infinitely malleable. This minimum core of European law of new health technologies may include implications such as obligations to ensure adequate information is given to users of new health technologies on the benefits and risks of their use; to help and protect people (the young, the very old, those who lack capacity) who are unable to make their own health care decisions; to ensure quality and safety of new health technologies for the public in general; and to ensure that new health technologies do not increase existing social inequalities. Such obligations flow from extant standards within the Council of Europe; most of them are also reflected in EU law. ${ }^{98}$

We also discern an increasingly accepted notion of a minimum core of procedural and institutional European law of new health technologies. European human rights law prescribes which interests have to be considered, promoted, and balanced in whatever regulatory framework is adopted (at national or transnational levels) and, to an increasing extent, the institutional arrangements through which these processes must take place. Although the substantive balance of these interests is contextually variable, the procedural requirement to consider relevant interests is non-negotiable. In the discourse, ${ }^{99}$ this minimum core includes strong notions of transparency, thereby facilitating broad public debates which are said to legitimate law and regulation of new health technologies. So, for instance, the ECtHR accepts stronger differences in approach, through the legal doctrine of the margin of appreciation, where there is evidence of wide public deliberation on the new health technology at issue. Indeed, for the ECtHR, 'good' European law of new health technologies is regularly reviewed and revised, taking into account not only developments in science, but also those in society. ${ }^{100}$ In the EU context, the notion of a 'competent authority', with obligations to report to the EU's institutions, used in the harmonization strategies of the EU in many of its legislative instruments, imposes a non-negotiable institutional obligation on Member States, even if the details of operation of national 'competent authorities' vary significantly. ${ }^{101}$

Finally, notions of the 'human' in human rights are likewise salient to European law of new health technologies. Generally, although not discussed directly in this collection

96 The consent principle, respect for private and family life.

97 The 'minimum core' identified in Chapter 3, Section XX in this collection.

98 With the possible exception of the last, although EU law does recognize the principle of inequality, and is committed to promoting 'health for all' in many of its policies, see European Commssion Communication on Solidarity in Health: Reducing Health Inequalities in the EU, COM (2009) 567 final.

99 Though would be difficult to defend the idea that this has been realized in practice.

100 Chapter 13, Section XX in this collection.

101 See Chapters 9 and 10 in this collection. 
in, say, discussions touching on the embryo in European law ${ }^{102}$ (or so-called 'posthumans'103), this salience is apparent in relation to, for instance, the question of the rights holder and who has rights protections in the field of xenotransplantation. ${ }^{104}$ In the EU the human holds rights, and the non-human is subject to weak welfare considerations, but is largely effaced from law. This process of the sequestration of the 'creaturely' in EU governance of new health technologies is, perhaps unsurprisingly, related to its specific concerns, especially around safety, and by implication its focus on markets, that is, ensuring consumption of products. By contrast, however, the Council of Europe, recognizes the unprecedented transpecies-hybridity of xenotechnologies and the need for more robust protections for the non-human. Overall, however, the nonhuman is largely 'rubbed out' of European law. Nevertheless, in this way the meaning of 'human' in human rights is highlighted in European law of new health technologies, raising the question: Are human rights themselves future proof? Of course, European law of new health technologies relies not only on human rights, but also on other nonmarket frames, such as ethics, to which we now turn.

\section{d. Ethics}

What about ethics, the final frame in our quartet? One point stands out: ethics, for a range of reasons, is hard to pin down. This seems true as a general claim; it is also true in the context that concerns us-European law of new health technologies. Why is this so? First, ethics has not been a dominant feature of the European policy landscape. ${ }^{105}$ True, ethics has been a strong frame in EU research funding regulation ${ }^{106}$ and in the use of human biological materials ${ }^{107}$ and the ECtHR does grant a wider margin of appreciation where there is no European consensus, 'particularly where the case raises sensitive moral and ethical issues'.108 However, none of these developments places ethics as a central influence on policy or on law. There is also a tendency, prevalent across the European law and policy landscape, to make references to ELSI (ethical, legal, and social implications), to 'ethics and rights' or 'law and ethics', or to 'sensitive moral or ethical issues'. These relentless linkages do not help when the question is: What is the role of ethics in European law of new health technologies?

Secondly, if we accept that European law is, or could be, influenced by the emerging international governance framework on new health technologies, ${ }^{109}$ we face a further problem: the 'bioethical triangle'. ${ }^{110}$ Human rights are a point of departure in the international framework, but they do not stand alone-rather, they are one part of an ethical plurality, sharing the regulatory terrain with both a dignitarian ethic and a

102 Itself implicated in several chapters, eg Chapters 2 and 13 in this collection.

103 I Karpin, 'The Uncanny Embryos: Legal Limits to the Human and Reproduction Without Women' (2006) 28 Sydney Law Review 599.

104 Chapter 16 in this collection.

105 Chapters 2, 3, and 14 in this collection.

106 See further the Regulator's Perspective in Part IV of this collection.

107 See Chapters 5 and 9 in this collection.

108 Evans (n 90).

109 See in particular the UN Declaration on Human Cloning 2005 and UNESCO's clutch of international biotechnology instruments: the UDBHR 2005, the International Declaration on Human Genetic Data 2003, and the Universal Declaration on the Human Genome and Human Rights 1997.

110 See eg R Brownsword, 'Human Dignity, Ethical Pluralism, and the Regulation of Modern Biotechnologies' in Murphy (n 2). 
utilitarian one. ${ }^{111}$ Occasionally, the plurality will converge around a consensus: more often, however, 'choices will have to be made'. 112

So-called 'regulatory ethics' adds to the difficulty. Even if we look only at medical ethics and bioethics, casting these as two forms of ethics that exert regulatory influence in Europe, we are faced with a range that includes academic, clinical or professional, corporate, and public bioethics. Each of these contributes to the governance of new health technologies and to what is, and what is not, seen as within (European) law's reach. For instance, to avoid the legal risk of rights, and other legal and non-legal risks, science and technology companies may work on 'ethical prophylaxis'; 113 in other words, on finding ways to protect their technologies by means of their own 'good practice'.

Academic bioethics, in the wake of the 2005 UNESCO Declaration on Bioethics and Human Rights, has spent time investigating not just the tensions within that Declaration but also two far broader questions: namely, could human rights subsume bioethics, and should it?114 Human rights lawyers-in Europe and elsewhere-have shown no particular interest in those questions or in the analyses being offered by bioethicists. Dignity has drawn their attention, ${ }^{115}$ and the Oviedo Convention has sparked interest too, but outside these developments there is little of note. ${ }^{116}$ The ECtHR, for its part, has been less than encouraging: giving advice on Recommendation Rec(2003) 10 of the Committee of Ministers concerning xenotransplantation, representatives of the Court suggested that the ECHR 'should be understood as a legal instrument aimed at securing individual rights and as such it may be of limited relevance to policy issues in the field of bioethics.' ${ }^{117}$ So is the ethics frame a sideshow or even an irrelevance in European law of new health technologies?

The answer is that ethics is neither a sideshow nor irrelevant: in what follows we explain why. Let's start with public bioethics-whether that be the EGE or an ethics advisory group in a particular European state. ${ }^{118}$ For us, this is a particularly interesting regulatory force. Our decision to include a set of regulators' perspectives testifies to our interest: several of these regulators serve, or have served, on bodies that are engaged in

111 See eg Universal Declaration on Bioethics and Human Rights (UDBHR), Art 2(d).

112 H Somsen, 'Regulating Human Genetics in a Neo-Genetic Era' in Murphy (n 2); see the notion of 'ethical subsidiarity' in Chapter 16 in this collection.

113 The phrase comes from S Franklin, 'Ethical Biocapital' in S Franklin and M Lock (eds), Remaking Life \& Death: Toward an Anthropology of the Biosciences (SAR Press 2003). She notes that ethical concerns are increasingly being 'built into' new life forms, as eg, in the development of a stem cell extraction procedure which removes one cell from the blastocyst without impinging on its ability for further development.

114 See eg Chapter 14 in this collection, and RE Ashcroft, 'The Troubled Relationship Between Human Rights and Bioethics' in MDA Freeman (ed), Law and Bioethics: Current Legal Issues, vol 11 (OUP 2008).

115 See eg C McCrudden, 'Human Dignity and Judicial Interpretation of Human Rights' (2008) 19 European Journal of International Law 655; T Murphy, 'Taking Revolutions Seriously: Rights, Risk and New Technologies' (2009) 16 Maastricht Journal of European and Comparative Law 15.

116 Doing human rights 'ethically' is an emergent theme (see eg T Murphy, 'Public Health Sans Frontières: Human Rights NGOs and "Stewardship on a Global Scale"' (2011) 62 Northern Ireland Legal Quarterly 659) but this has not translated into increased interest in rights, ethics, and new health technologies.

117 Draft Memorandum to Recommendation $\operatorname{Rec}(2003) 10$ of the Committee of Ministers to Member States on Xenotransplantation-Explanatory Memorandum. 5 June 2003, CM(2002) 132 Addendum, at Appendix <http://wcd.coe.int/ViewDoc.jsp?id = 45827> accessed 18 July 2012. Cf 'Research Report: Bioethics and the Case-law of the Court' (Council of Europe/European Court of Human Rights, 2012) <http://www.echr.coe.int> (Case-law-Case-Law Analysis-Research Reports).

118 The UK's Nuffield Council on Bioethics being one illustration. 
public bioethics. ${ }^{119}$ What we cannot do, however, is specify the nature or the extent of the regulatory force that is being exerted by this form of ethics. Equally, we cannot say whether it has a distinctive 'European-ness' to it. Hence, our proposal for work diagnosing why, policy-wise, bioethics has been the 'go to' discipline for contributory expertise (rather than say law or, within that, human rights law). We also called for work that examines how individual advisory groups treat legal knowledge and, indeed, legal experts where they form part of the membership. ${ }^{120}$

Work of this sort is important because it will bring to light whether and how public bioethics expresses and fosters European (and not just EU) citizenship or, what STS calls, 'biological citizenship' (and the related matter of who- or what - is excluded or largely effaced, that is, the non-human). ${ }^{121}$ It will also help us to dissect claims that public bioethics plays another, rather different role-of providing a focus for expertgenerated discourse, which produces and legitimates an expert-led EU regulatory environment that supports innovation. ${ }^{122}$ Finally, it should help us to answer the interesting question of whether there is a European bioethics and allows us to discern the reach, content, and meaning of that bioethics. ${ }^{123}$

For now the answer we give to the question of whether there is a Europena bioethics is 'no' (or at least not yet). Any claim that the precautionary principle constitutes such a European bioethic can be dismissed because as yet, even in the apparently advanced engagement by the EU, this principle has neither an agreed meaning nor a commonly accepted normative force. ${ }^{124}$ In similar vein, if we look at Council of European law, any claim focusing on dignity as the core European bioethics also needs to be dismissed or, at all events, put on hold. ${ }^{125}$ Obviously, for some, the place of dignity in the EUCFR is grounds for optimism. ${ }^{126}$ And, looking ahead to an EU that has acceded to the ECHR, we may imagine an enhanced role for the dignity, focused Oviedo Convention. ${ }^{127}$

However, in tension with this notion of a European law of new health technologies founded on a European bioethic of dignity, we see the EU as a framework within which ethical differences are managed, in the pursuit of the 'prize' of creating and sustaining the internal market, and a sufficiently globally competitive industry. ${ }^{128}$ The ethics of actually providing patient access to new health technologies ${ }^{129}$ are not the subject of European law. ${ }^{130}$ Perhaps this should not surprise us: ethical questions are a 'national matter' in EU contexts, and the ECtHR sees the lack of a European consensus, 'particularly where the case raises sensitive moral or ethical issues', as one of the triggers

119 See the Regulator's Perspectives in Parts I, II, III and IV of this collection.

120 For these proposals, see Chapter 13 in this collection.

121 Chapter 16 in this collection.

122 Chapters 2 and 16 in this collection.

123 This question is posed in Chapter 14 in this collection.

124 See the discussion in Chapter 14 in this collection. For a developing argument on the principle's role in a rights-based community, see Brownsword (n 21) and Brownsword and Goodwin (n 21).

125 Chapter 3 in this collection.

126 Chapter 9 in this collection.

127 Chapter 14 in this collection.

128 Chapters 2 and 6 in this collection; Syrett in this collection.

129 Say, to members of vulnerable groups such as those suffering rare diseases.

130 Save, perhaps, emergent Council of Europe law on the 'right to health' combined with the principle of equality; and, perhaps, the emergent governance processes in the EU's promotion of exchange of information between national health technology assessment agencies: see, respectively, Chapters 3 and 2 in this collection. 
for a wide margin of appreciation. ${ }^{131}$ In any event, if we are seeking a European bioethic, as a central frame or feature of today's European law of new health technologies, both precaution and dignity fall short of the mark.

Still, the EU's 'ethical market' - an idea developed in a number of chapters-seems an interesting offshoot of the question about a European bioethic. Might it be an entity that is at once distinctly European and distinctly ethical? And by drawing in the European Patent Convention, with its reference to morality, ${ }^{132}$ could we broaden this ethical market beyond an EU-identity? Could we also draw in the Council of Europe and, in so doing, introduce the idea of a human rights-based market? The potential is there. On the other hand, there are grounds to be doubtful. The EU successfully navigated significant differences over the ethical dimensions involved in the donation of blood, human tissue and cells, and organs. To do so, the EU invoked the authority of the Council of Europe in matters concerning ethics and human rights. The reality of the market (particularly in blood) in Europe was almost entirely suppressed in the text of the relevant legislation. ${ }^{133}$ We would do well to be sceptical over whether this market-suppressing approach contributes to the effective management of risk, especially in clinical settings. Likewise, EU law on gamete donation asserts that it is based on an ethic of altruism, ignoring the very real market in gametes (both for infertility treatment and for stem cell research) and the different positionings of women and men, and of different women, in this market. ${ }^{134}$

In summary, then, although we have shown that the place and roles of ethics in our new field of inquiry_European law of new health technologies—are important, for now we cannot do much more than raise some of the questions as to why this is so and point to importance of following up this frame.

\section{Frames in Combination}

a. Markets and...

In general, ${ }^{135} \mathrm{EU}$ law of new health technologies conceives the need to protect against risks as fundamentally linked to the market frame. The need to safeguard patients, consumers, or public health from undesirable outcomes, in the context of uncertainty, is justified by the need to create and sustain markets in those new health technologies. We see this in the range of EU law on new health technologies, including product safety and product liability legislation. This legitimation of European law of new health technologies is found strongly in EU law, but also seems to be associated with other legal orders, such as the World Health Organization (WHO), ${ }^{136}$ although it is not represented in Council of Europe law.

Our case studies show that, in general, markets and risk reinforce one another in EU law in two closely related ways - either a risk narrative supports the market frame, or the risk narrative is embedded within the market frame. Areas such as EU law on research

131 See, respectively, Chapters 2, 13, and Z in this collection.

132 Odell-West in this collection.

133 Chapter 7 in this collection.

134 Chapter 17 in this collection.

135 Although we note here that we were unable to agree whether this holds true for EU law on the human body and new health technologies; further investigation would be necessary to resolve this difference of opinion.

136 Chapters 2, n 102 in this collection. 
funding, research processes, intellectual property, and product safety are all examples of these connections between markets and risk. The constant reference point in these areas of EU law is the aim of getting new products or services to market, in such a way that consumers will have confidence in their quality and safety. ${ }^{137}$ The legitimacy of regulatory management of uncertainties and risks entailed in new health technologies is assessed by reference to the ways that it supports the EU's market in new health technologies.

Having said that, a more nuanced approach is required if we are to understand the interrelationship between risk and markets in the context of European law regarding the collection and supply of human biological materials, whether in their raw form or as part of tissue engineered products. Running strongly through European social thought is the need to avoid the instrumentalization or commodification of the human body. This has become embedded not only in key (bio)ethical texts and declarations, but also in rights-based legal instruments such as the EUCFR and the Council of Europe's Oviedo Convention. So how can this be squared with the commercial value that is now ascribed to such materials in the wake of scientific and technological advances?

Reliance has been placed on the ill-defined notion of human dignity to exclude the commodification of, as well as trade in, such materials. ${ }^{138}$ This is at odds with the reality of a thriving and lucrative European and, indeed, global market in human biological materials, such as blood and various types of tissue. These high-level ('constitutional') legal instruments may be read as one way in which the EU seeks to reconcile the relationship between risk and markets in this context. At the level of legislation, however, the EU does not fully acknowledge the dimensions of the market in the context of the design of the EU-wide blood regulatory regime for blood, for example. This failure has adverse implications not only for facilitating effective risk governance in the context of market activity, but also for broader questions concerning regulatory legitimacy. ${ }^{139}$

In terms of legitimation, here we also see the idea that the EU's market itself embodies or embeds a particular approach to risk management, and that the EU's market is constructed as one which is safe for consumers/patients. ${ }^{140}$ Risk and market are also deployed to construct the EU as a democratic order. Risk operates in support of the market, which is therefore kept working, but at the same time also provides a way of making the EU capable of being audited and inspected as it relates to its citizens and broader publics. The risk/market narrative thus plays a key role in legitimating EU regulation.

The Council of Europe's approach to both risk and markets is more difficult to unravel. The ECtHR's approach to the 'right to health' may be seen as incorporating a 'precautionary' approach to risk, especially in the context of environmental threats to health, but also carried over into contexts concerning the right to information about an individual's health (such as results of genetic testing). ${ }^{141}$ In general, both markets and risk, and the market/risk nexus are much less visible in Council of Europe governance than in the EU context. Indeed, in SH and Others v Austria the Grand Chamber of the ECtHR, upholding Austria's ban on third party donation for IVF, mentions the

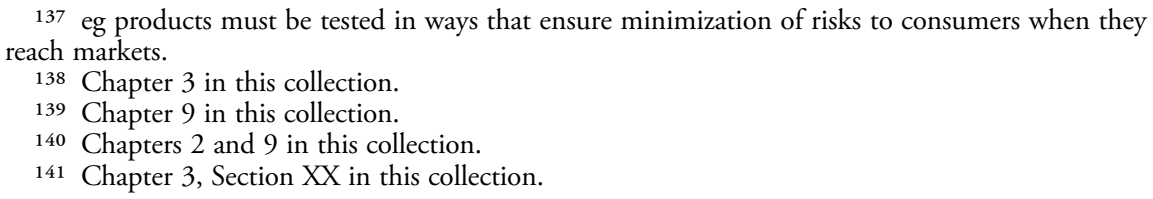


opportunity for Austrians to travel abroad for treatment and have their parental status recognized at home, yet it makes no mention of any of the risks that attach to crossborder reproductive care. ${ }^{142}$ So, if we are serious about a European (and not simply a European Union) law of new health technologies, we probably cannot characterize that law as constructed entirely through market-based legitimation of risk regulation.

To summarize, European law of new health technologies works to articulate the notion that the European market in new health technologies is safer, more respectful of human rights, and more ethical, than other markets. European law of new health technologies is thus constructed as the polar opposite of a 'global Vegas', where more or less 'anything goes'. European institutions have to grapple with a balance between, on the one hand, a totalizing discourse which pushes 'European' standards towards higher standards (a position associated with the European North and West), so that no one can 'escape', and a notion of European diversity and pluralism, or even regulatory competition (a position associated with the European East and South), which enhances choice (for those who can move within Europe). ${ }^{143}$ Choice itself, as a core manifestation of autonomy in the human rights and ethics frames discussed later, is thus a legitimating factor in European law of new health technologies.

The apparent primacy of the market in the European context might be disrupted, for example, by the EUCFR and its relation to the ECHR. If the EUCFR represents how the EU characterizes and formulates governance (with respect to new health technologies), by reference to human rights, in terms of its immanent, self-proclaimed values, this if demonstrated would represent a fundamental change to the EU's self-representation as understood here. The implications of that discourse include that the EU is not a market organization, or not just a market organization, with its regulatory activities legitimated by reference to the efficiency of markets. Rather, the EU would be laying claim to the legitimating elements of human rights, and resonating with the heritage of the Council of Europe, to justify its regulatory activities. But while this discourse is discernible at the level of abstract legal instruments (such as the EUCFR), it disappears almost entirely when the frame or scale of reference ${ }^{144}$ changes to the detail of legislation or regulatory norms.

\section{b. Human rights and ethics}

Earlier we mentioned 'ELSI'-ethical, legal, and social implications of new health technologies. We were unable to tease out the relationships between the individual components; doing so is, we think, an important ongoing task-one that calls not for grand diagnoses but for close, careful studies of legal and non-legal sites where decisions are made about what is ethical, what is legal, the links between them, ${ }^{145}$ and so on. Imagine, however, that it is not ELSI but rather 'ethics and human rights', a combination of two of our four frames, which needs to be dissected. Is this more straightforward? Maybe, but it is not by much.

One challenge is that human rights manifest as law and as discourse. ${ }^{146}$ 'Ethics and human rights' will have different meanings depending on whether one reads

142 Chapter 13 in this collection.

143 Chapter 17 in this collection.

144 Da Sousa Santos (n 16).

145 R Brownsword, 'Bioethics: Bridging from Morality to Law' in Freeman (n 114).

146 Chapters 2, 13 and 17 in this collection. 
'human rights' to mean law, discourse, or both. And where the combination changes to 'ethics and rights', other possibilities—consumer rights, rights for non-humans ${ }^{147}$ will emerge.

Both the recent and the more distant past produce challenges too. Some may tell a story of the birth of human rights and bioethics in the Nuremberg Trials, and of overlapping or shared experiences subsequently (notably around the rise of informed consent), thus claiming a 'European-ness' to human rights and ethics as a feature of European law of new health technologies. Yet origin stories are always controversial and others will downplay, or even dismiss, these overlaps between human rights and bioethics.

The recent past, too, is unlikely to produce consensus on the relationship between ethics and rights. It has, to be sure, been a time of internationalization and institutionalization: there has been almost a 'race to the top' for ethics and human rights, both separately and in tandem. One instance of the latter is the 2005 UNESCO UDBHR. ${ }^{148}$ Another is the rise of an 'almost unquestionable presumption' that it is best for children to know about the gamete donor(s) who played a role in their conception. ${ }^{149}$ This presumption draws both from the ethical notion of 'best interests' and from the human rights commitment to respect for private life ${ }^{150}$ (and, in places, from the impropriety of state-supported deception ${ }^{151}$ ). A third illustration is provided by EU orphan medicines legislation. ${ }^{152}$ The aim of this legislation is to entitle patients suffering from rare conditions to the same quality of treatment as other patients, which we may see as 'equity' and 'non-abandonment' (a notion reflected in the very term 'orphan'), meaning a combination of an ethic of solidarity (which is embedded in European health care systems) and the right to equal treatment.

Turning to the EU's general approach to regulating new health technologies, ${ }^{153}$ we may be more explicit again. In general, ethics and (human) rights in this context can be melded, as their roles in EU regulation of new health technologies are similar. We particularly note 'an ethics or (human) rights-based approach to markets' in three areas: first, research funding and intellectual property rights promoting research; secondly, safety in research processes and products; and, thirdly, consent in research processes. Of course, even if the overall conclusion is that rights and ethics are used 'more as a means of legitimating other framing choices than as a frame in themselves', 154 this too is a melding of rights and ethics.

But 'in tandem' is not the only, or even the dominant, mode for ethics and human rights. The UDBHR - a universal declaration on bioethics and human rights-has already attracted a wide range of criticism. ${ }^{155}$ Meanwhile, as noted earlier, European law (both the law of the EU and that of the Council of Europe) has effaced the animal (and with it the ethic of animal welfare), placing humans (with their human rights) in the centre of its frame. ${ }^{156}$ There has also been concern at the 'demoralisation of

147 Chapter 16 in this collection.

148 Chapter 14 in this collection.

149 Chapter 17 in this collection.

150 It is not clear if the ECtHR would back this 'right to know' to the exclusion of competing rights and interests: see eg Odièvre v France (n 87).

151 Discussing the United Kingdom, see J McCandless, 'The Changing Form of Birth Registration?' in F Ebtehaj and others (eds), Birth Rites and Rights (Hart 2011).

152 Chapter 6 in this collection.

153 Chapter 2 in this collection.

154 Chapter 2 in this collection, $x$.

155 Chapter 14 in this collection.

156 Chapter 16 in this collection. 
medicine' - a trend attributted in part to the manner in which rights-based systems can corrode trust in professionals and in professional ethics, and potentially pitch law against ethics in damaging ways. ${ }^{157}$

Imagined futures, too, offer different prognoses on the rights/ethics relationship in European law of new health technologies. For instance, does human rights, because of its capacity for empowerment, have an edge over bioethics? ${ }^{38}$ Is it, in other words, seen as more 'future proof?'We could, of course, imagine a developing normative framework for European governance of biomedicine, and the institutionalization of a human rights approach, through a transposition of the Oviedo Convention from its rather minor role as a persuasive authority in the interpretation of the ECHR, to a rather more important role as a guiding set of principles for the governance of biomedicine within the EU.159

Yet inquiry not imagination is what is required. The best prescription, therefore, has to be close study of the relevenace of the interactions (or not) of ethics and human rights (as law and as discourse) in both legal and non-legal sites where the governance of new health technologies is determined or, indeed, resisted. ${ }^{160}$ In this way we might begin to understand the relationships between these modes of governance and, of course, whether there is a certain European-ness to any of them, standing alone or in combination.

\section{Agendas Going Forward}

So, in light of our findings, we move now to reflect on agendas for future research. Much supranational governance has been focused on the promotion of trade and international markets. While this may not be a problem in some areas, it is in the case of technologies that have the potential to impact upon human health and wellbeing. Legal and regulatory responses to technologies beyond the nation-state at the supranational level present persistent problems for legitimacy and legitimation, and law's role in this regard is likely to be vital. The contributions to this book have made a start in addressing these problems, simply because health matters, it is political, and it affects citizens directly.

More specifically, in the foregoing discussion of the defining features of European law of new health technologies, credibility, trust, and accountability are raised, and the roles of markets, risk, human rights, and ethics in promoting those have been discussed. In this context of the four frames as legitimating devices, we might typify markets as preoccupied with efficiency; risk as preoccupied with safety; human rights as preoccupied with freedom and dignity; and ethics as preoccupied with freedom, dignity, justice, and 'fundamental morality'. Understood thus, these four legitimating frames claim (mostly) mutual separation. For instance, the regulatory legitimacy which follows from efficiency is mutually inconsistent with that which follows from safety, freedom and dignity, or justice, and so on. We might say, then, that European law of new health

\footnotetext{
157 J Montgomery, 'Law and the Demoralisation of Medicine' (2006) 26 Legal Studies 185. He does accept, however, that rights - notably ECHR rights—-have, within them, a capacity to 'remoralise' medicine.

158 Ashcroft (n 114).

159 Arguing against the 'cynical story' about bioethics, the international human rights movement, and the UDBHR, see TA Faunce and H Nasu, 'Normative Foundations of Technology Transfer and Transnational Benefit Principles in the UNESCO Universal Declaration on Bioethics and Human Rights (2009) 34(3) Journal of Medicine and Philosophy 296.

160 Chapter 13 in this collection.
} 
technologies has very disparate and even contradictory claims to legitimacy. This requires further study.

Further, several of the chapters consider the extent to which the aspects of European law upon which they focus are legitimate, defined in various ways, including by reference to effectiveness, to fairness or equality, to democracy or accountability. Their findings suggest, in general and overall, that both political and institutional legitimacy with respect to the use of (new) health technologies is a salient issue and at the same time is problematic for supranational polities, such as those occupying the European space. Traditional methods of achieving legitimacy may not be possible at supranational level, given the existence of non-majoritarian institutions and decisionmaking processes. ${ }^{161}$ As such, techniques of legitimation become important. We have focused on the use of law (broadly defined) as a key legitimation technique in various guises. But further attention is required to tease these out, begging at least one question: In what areas are new legal techniques in need of development, what shape should they take, and what values should they seek to uphold?

Moreover, in asking what the roles of markets, risk, human rights, and ethics are in the legitimation of European law on new health technologies, we are also asking a question of a different order. We are interested not so much in the legitimacy of European law's approach in terms of its outcomes, but more in how these ideas are used as ways of legitimating regulatory purposes and practices—and, indeed, of legitimating ideas of 'Europe' itself. Overall, then, there is a need to examine both legitimacy and legitimation in greater depth.

Secondly, we need to explore further the promise and the pitfalls (for legal modes of governance, for legal method, and more broadly for the governance of new health technologies) of particular ways of seeing law. The ECtHR, as we have seen, has faith in law-technologies may be fast-moving, they may even be a threat to human rights but law can, does, and should, move in ways that are a match for this. For the ECtHR, then, law is not fundamentally unsuited for the challenges posed by new health technologies. Yet this notion of faith in law is strongly challenged in the 'empirical realist' account of two of the sociologists who contributed to this collection: for them the law, far from being benign or protective of dignity and freedom, is an instrument of already powerful actors, and thus perpetuates (undesirable) relationships that are fundamentally unequal. ${ }^{162}$ The upshot is that both faith in law and no faith in law merit further study, as do the range of positions in-between.

As part of this might be asked: Is there something specific to European law that could justify faith in it —or a leap of faith? In particular, how does — or could — that law deal with the future, with degrees of uncertainty, and with the scope for unknowing (in a scientific sense) inherent to new health technologies in Europe's context of intense internal cross-borderness? How is this to be described? In the context of European law's ongoing experiment in melding universalism and particularism, via doctrines such as the margin of appreciation, the notion of 'European consensus', the doctrine of subsidiarity, or locally crafted compliance with generally framed obligations as in the case of EU Directives, does this amount to a new way of thinking about—and doing-law?

A third area for further exploration concerns relationships between law, new health technologies, and identity. In ongoing processes, European institutions essentially seek to construct an identity that is distinct as compared to other (global) regulators. For

161 A notable exception being the European Parliament.

162 Chapter 11 in this collection. 
example, the EU's projection of its identity as a supranational order founded on the rule of law (as framed and legitimated around markets) is used to underpin a process of knowledge production leading to application in material objects, such as new health technologies. In addition, this collection offers a few glimpses into the complex, interacting, and mutually constitutive techniques, practices, and processes of the 'making up' of both individual and collective identity in relation to European law.

For instance, even as state practices often remain distinct, ${ }^{163}$ European law and its constitutive features of markets, ethics, risk, and rights, work with technoscience, (biomedical) knowledge, and imagined futures to provide a basis for individual and collective identification, 'European-ness', or European biocitizenship. This can be seen in the ways that 'other' hospitals, research centres, products, and technoscientific processes are increasingly being used, consumed, and thought of as not so foreign. These offer multiple means of identification: European citizens, European consumers, and now European patients. The permutations of these, as well as who is includedEuropeans and non-Europeans who are affected by European law?- and law's roles in fabricating identities, such as through instantiations of imagined technoscientific futures, are ripe for further exploration.

There is scope for consideration of whether and, if so, to what extent, and which, Europeans (and even non-Europeans) are enrolled in European law (or not). What are the rationales for their involvement? That is, to what extent is citizen or public participation truly an effort to mobilize and facilitate substantive involvement in European law, and to direct and shape the material outputs of new health technologies? Are such efforts, for instance in the field of synthetic biology, merely attempts at legitimating governance that regulate and seek to calm citizen discontent and contestation? ${ }^{164}$ How are biocitizens making use of traditional legal sites and fora (such as courts) in order to demand and contest decision-making over new health technologies and life itself? 165 What newer or alternative legal sites and fora are being used—or might be needed - in order to facilitate involvement? Who is included and who is marginalized and silenced and even excluded in attempts to demand and contest decision-making?

Moreover, identities change: the WHO estimates that by 2020 depression will be the second largest cause of morbidity worldwide. ${ }^{166}$ For this and other reasons, the neurosciences now command considerable attention-from states and from others too. ${ }^{167}$ What new European biocitizens_-and non-European biocitizens - might emerge from this increasing centrality of neurology and mental health care? Do ECtHR judgments on the rights of mental patients, and the associated rights-activist tradition within some European states, notably the United Kingdom, give Europe a degree of legal preparedness? Or are these 'old' rights ill-suited to emergent science, illness, and patient activism? And, more than this, are rights—or at least rights as law—entirely the wrong frame?168

163 Chapter 17 in this collection.

164 ML Flear, 'The EU's Biopolitical Governance of Advanced Therapy Medicinal Products' (2009) 16 Maastricht Journal of European and Comparative Law 113; ML Flear and MD Pickersgill, 'Regulatory or Regulating Publics? The European Union's Regulation of Emerging Health Technologies and Citizen Participation' (2013) xx Medical Law Review xx).

165 A potential and practice highlighted in at least a couple of contributions, eg NGO interveners at Strasbourg in Chapter 13 in this collection; identity issues identified by Chapter 17, Section XX in this collection.

166 See <www.who.int/mental_health/management/depression/definition/en/>.

167 See further J Abi-Rached and N Rose, Neuro (Princeton UP 2012 forthcoming).

168 For views, see N Rose, 'Unreasonable Rights: Mental Illness and the Limits of the Law' (1985) 12 Journal of Law and Society 199; LO Gostin, 'From a Civil Libertarian to a Sanitarian' (2007) 34 Journal of Law and Society 594. On ECtHR case law, see P Bartlett, O Lewis, and O Thorold, Mental Disability and the European Convention on Human Rights (Martinus Nijhoff 2006). 
Fourthly, there is scope for more comparative scholarship. Ultimately, a claim to the effect that a 'European law of new health technologies' is distinctive would be more convincing in the context of comparison to other governance systems. ${ }^{169} \mathrm{We}$ would like to know, for instance, is there a 'law of the Americas of new health technologies', or an 'Asian law of new health technologies'? There is also scope for a more thorough comparison of European law of new health technologies with the emerging international framework.

A final question is that of the redistributive consequences of European law of new health technologies. The frame of law ${ }^{170}$ which we have adopted in this book, and the focus on the European level, in themselves diverted us from a thorough consideration of the redistributive consequences of what we have explored here. Some of our contributors do consider questions of redistribution-who are the 'winners' and 'losers' in European law of new health technologies? ${ }^{311}$ But there is much more work to be done here to unravel what it means for redistribution, which in the current pluralist European constitutional settlement is a matter for national or sub-national governments and governance processes - although the Eurozone bailout deals are already having a significant influence on European health systems. ${ }^{172}$ It is unimaginable that the contexts within which that redistribution must take place remain unaffected by European law of new health technologies. But what are the implications?

Related questions are about regulation through control of resources ${ }^{173}$ and, crucially, about relationships between redistribution, ethics, and human rights. If the EU wishes to be recognized as a global human rights actor, ${ }^{174}$ and if the ECtHR wants to live up to the claim that it is 'the jewel in the crown of the world's most advanced international system for protecting civil and political liberties', ${ }^{175}$ each needs to think carefully about the right to enjoy the benefits of scientific progress and its applications, ${ }^{176}$ about the obligation of international cooperation and assistance, and relatedly, about how a human rights conception of intellectual property might differ from existing ways of promoting innovation and creativity. International human rights law and practice, as well as developing states and a range of NGOs and INGOs, are engaging with these questions. ${ }^{177}$ Scholars, too, are interested. ${ }^{178}$

Yet the EU, like the USA, has been pursuing bilateral agreements, known as TRIPsplus, seeking to avoid TRIPs flexibilities that allow states to use public health needs to invoke compulsory licensing. The ECtHR for its part has had little to say on crossing

169 But note Theodore Marmor's warning against unthinking comparison of health systems, see T Marmor, RB Freeman, and K Okma, 'Comparative Perspectives and Policy Learning in the World of Health Care’ (2005) 7 Journal of Comparative Policy Analysis, 331.

170 Though in its broader governance contexts.

171 Chapters 6, 11, 13, and 17 in this collection.

172 N Fahy, 'Who is Shaping the Future of European Health Systems?' (2012) 344 British Medical Journal 1712 .

173 What Daintith calls 'government by dominium': see T Daintith, 'The Techniques of Government' in J Jowell and D Oliver (eds), The Changing Constitution (OUP 1994) 209.

174 See eg G de Búrca, 'The EU in the Negotiation of the UN Disability Convention' (2010) 35 European Law Review 174.

175 Helfer (n 31).

176 See eg International Covenant on Economic, Social and Cultural Rights (adopted 16 December 1966, entered into force 3 January 1976) 993 UNTS 3 (ICESCR), Art 15(1)(b).

177 See eg Venice Statement on the Right to Enjoy the Benefits of Scientific Progress and Its Applications 2009 <http://shr.aaas.org/article15/Reference.Materials/VeniceStatementJuly2009.pdf> accessed 16 July 2012; 'The Right to Enjoy the Benefits of Scientific Progress and Its Applications': Report of Farida Shaheed, Special Rapporteur on cultural rights, UN Doc A/HRC/20/26 (14 May 2012).

178 See eg T Pogge and others (eds), Incentives for Global Public Health: Patent Law and Access to Essential Medicines (CUP 2010); M Sunder, From Goods To A Good Life: Intellectual Property and Global Justice (Yale UP 2012). 
borders for health purposes - whether Europeans crossing borders to other European states or further afield, or seriously ill non-Europeans being returned to their countries of origin. ${ }^{179}$ All of these phenomena have serious redistributional consequences. They also limit the prospects of European law of new health technologies as an experiment in ethical or human rights-based markets. That observation concludes our main candidates for future directions, and it brings us to our final question.

\section{Conclusion}

Where are we, at the end of our project? Our overall argument runs something like this. Together, the detailed analyses within this book demonstrate that, taking a broadbrush, high-level view, there is sufficient cohesion around the legitimating factors of markets, risk, human rights, and ethics, alone and in various combinations, to justify our claim to have created a new field of scholarship: European law of new health technologies. Our 'map' of that new legal field sets out its broad parameters, identifies its key features, and establishes an agenda for both research and reform into the future. We are not claiming that European law of new health technologies is a unitary or unified legal system-rather, it is a pluralist network of legal sites, focused around a legitimating process of determining 'European-ness'. This is not a surprise, as Europe's identity is (and probably always will be) a process, and the institutional and legal instantiations of 'Europe' (the Council of Europe, the EU, and so on) relate to and co-construct the very notion of what it is to be 'European'. One of the tantalizing features of that 'European-ness' is the promise of escape from the globalizing force of market power. For sure, markets are writ large in the legitimation of European law of new health technologies. But they do not tell the whole story. And that is why European law of new health technologies represents a perfect case study for reflecting on power, democracy, legitimacy, global justice, and redistribution: some of the most salient issues in our fast changing world.

179 On the latter see the ECtHR judgments in $D v$ United Kingdom and $N v$ United Kingdom, discussed in Chapter 3 in this collection. 